\title{
Openness, Country Size and Government
}

\section{Citation}

Alesina, Alberto, and Romain Wacziarg. 1998. Openness, country size and government. Journal of Public Economics 69(3): 305-321.

\section{Published Version}

doi:10.1016/S0047-2727(98)00010-3

\section{Permanent link}

http://nrs.harvard.edu/urn-3:HUL.InstRepos:4553014

\section{Terms of Use}

This article was downloaded from Harvard University's DASH repository, and is made available under the terms and conditions applicable to Other Posted Material, as set forth at http:// nrs.harvard.edu/urn-3:HUL.InstRepos:dash.current.terms-of-use\#LAA

\section{Share Your Story}

The Harvard community has made this article openly available.

Please share how this access benefits you. Submit a story.

\section{Accessibility}


NBER WORKING PAPER SERIES

OPENNESS, COUNTRY SIZE AND

THE GOVERNMENT

Alberto Alesina

Romain Wacziarg

Working Paper 6024

NATIONAL BUREAU OF ECONOMIC RESEARCH

1050 Massachusetts Avenue

Cambridge, MA 02138

May 1997

This research is supported by NSF Grant SBR-9511420 administered by the NBER. We thank Xavier Gabaix, David Laibson, Jack Porter, Antonio Rangel and participants in the macro workshop at Harvard for useful comments and suggestions. This paper is part of NBER's research programs in Economic Fluctuations and Growth, Monetary Economics and Public Economics. Any opinions expressed are those of the authors and not those of the National Bureau of Economic Research.

(C) 1997 by Alberto Alesina and Romain Wacziarg. All rights reserved. Short sections of text, not to exceed two paragraphs, may be quoted without explicit permission provided that full credit, including $(\mathbb{C}$ notice, is given to the source. 
Openness, Country Size and the Government Alberto Alesina and Romain Wacziarg

NBER Working Paper No. 6024

May 1997

Economic Fluctuations and Growth, Monetary

Economics and Public Economics

\begin{abstract}
This paper shows that smaller countries have larger public sectors as a share of GDP, and are also more open to trade. These empirical observations are consistent with recent theoretical models explaining country formation and break up.
\end{abstract}

\author{
Alberto Alesina \\ Department of Economics \\ Harvard University \\ Cambridge, MA 02138 \\ and NBER \\ aalesina@harvard.edu
}

\author{
Romain Wacziarg \\ Department of Economics \\ Harvard University \\ Cambridge, MA 02138
}




\section{Introduction}

A large body of literature deals with the economic determinants of government size, the determinants of trade openness and the relationship linking these two variables. Recent studies of the economics of country formation, by Alesina and Spolaore (1997) and Alesina, Spolaore and Wacziarg (1997) suggest that country size, government size and trade openness are interconnected. In particular, these papers have put forward two hypotheses:

1) Country size emerges from a trade-off between the economies of scale in supplying public goods in large countries, and the costs of cultural and ethnic heterogeneity, which may be increasing in the size of countries (Alesina and Spolaore (1997)). This result hinges critically on the assumption that, when you can share the costs of partially or completely non-rival public goods over larger populations, per capita expenditure on these goods are lower.

2) To the extent that market size influences productivity, large countries can "afford" to be closed, while small countries face stronger incentives to remain open; conversely, as trade liberalizes, regional and cultural minorities can "afford" to split because political borders do not identify the size of the market; therefore, smaller countries can enjoy the benefits of cultural homogeneity without suffering the costs associated with small 
markets (Alesina, Spolaore and Wacziarg (1997)). This hypothesis points toward a negative relationship between country size and the degree of trade openness.

This paper provides empirical evidence consistent with these two ideas. We first show that government consumption, as a share of GDP, is smaller in larger countries. We next confirm the observation that small countries tend to be more open to international trade.

These two facts, taken together, imply that open countries have larger governments. In a recent and widely cited paper, Rodrik (1996) resurrects an "old" idea by Cameron (1978), and suggests a different link between openness and government size. $\mathrm{He}$ argues that open countries are more subject to external shocks, and therefore need a larger public sector to provide a stabilizing role. The present paper implies an alternative explanation for the positive empirical relationship between openness and government size; specifically, we argue that this link is mediated by country size. Hence, we cast some doubts on the direct link between openness and the share of government consumption. On the other hand, we do uncover a direct relationship between openness and the size of government transfers, a result which is in the spirit of Rodrik's hypothesis concerning the stabilizing role of governments in open economies.

This paper is organized as follows. Section 2 discusses the argument linking country size, openness and government share and presents some simple statistics on this 
point. Section 3 specifies and estimates a more complete set of equations for the determination of government size and trade openness. Section 4 discusses the evidence concerning the direct effect of openness on government size. The last section concludes.

\section{Size, Openness and Public Goods.}

\subsection{Country Size and Trade Openness}

In several models with increasing returns to the scale of production, market size influences the level of economic activity. We can go back as far as Adam Smith, who argued that the size of the market imposes a constraint on the division of labor. Small countries that are closed to trade, in this context, must experience a lower overall level of productivity. More recently, Murphy, Shleifer and Vishny (1989) propose a model of industrial development in which market size determines the extent to which firms can benefit from positive spillovers from each other. In this model, low income countries may need a 'Big Push' in order to move from a 'bad' equilibrium characterized by traditional, constant returns technologies to a 'good' equilibrium with modern, increasing returns industries. Ades and Glaeser (1994), Wacziarg (1997) and Alesina, Spolaore and Wacziarg (1997) provide empirical evidence consistent with these ideas: large countries experience smaller dynamic gains from trade than smaller countries. 
In a world without international trade, political boundaries identify markets and countries face economic incentives to be large. On the contrary, the more a country can trade with the rest of the world, the less one can identify its political borders with the boundaries of its market. This observation has two implications: as the trade regime becomes more and more open, various ethnic groups and regions will find it feasible to break away from their original countries; more generally, countries will find it less costly to split. Conversely, as the world becomes more and more populated by small countries, a liberal trade regime will find more and more supporters, precisely because small countries need trade to be economically viable. In other words, small countries face incentives to adopt open trade policies, precisely because they cannot benefit from access to larger markets unless they are open to trade. Thus, small countries can be expected to be more open to trade.

Alesina, Spolaore and Wacziarg (1997) document the effect of trade openness on country size, i.e., on secessions and mergers. They start from some well known facts. After the Second World War, in a period of rapidly increasing trade liberalization, the number of countries increased from 74 in 1946 to 192 in 1995. In 1995, 87 countries had less than 5 million inhabitants, 58 less than 2.5 million and 35 less than 500,000 . More than half of the world's countries are smaller (in population) than the state of Massachusetts. ${ }^{1}$ Many factors have contributed to this development, particularly the decolonization of Africa and the collapse of the Soviet Union. However, the trade

\footnotetext{
In 1990 the State of Massachusetts had a population of 6,016,425. 98 countries have smaller populations.
} 
regime is also important. For instance, several new small countries that emerged in the former Eastern bloc may not have chosen independence in a world of heavy trade restrictions. $^{2}$

Other arguments also point to the fact that smaller countries should trade more, with causation running from country size to observed trade volumes directly, rather than through trade policy. A simple way to illustrate this type of argument is to undertake a simple thought experiment: Consider a large country living in autarky; if this country breaks up into smaller, free-trading units, each new unit will suddenly exhibit positive international trade.

\subsection{Country size and the size of government.}

To the extent that there are fixed costs and economies of scale linked to partial or complete non-rivalry in the supply of public goods, smaller countries may have a larger share of government in GDP. For instance, there are fixed costs in establishing a set of institutions, a legal, monetary, and fiscal system. At least up to a point, when congestion effects becomes relevant, the costs of certain public goods grow less than proportionally to the size of the population (parks, libraries, roads, telecom infrastructures). For some of these public goods, population density is also a critical factor (we control for this variable in our empirical analysis).

\footnotetext{
${ }^{2}$ Note that several new countries in Eastern Europe and the former Soviet Union are quite small. For instance, Latvia has 1.7 million inhabitants, Turkmenistan 4 million, Moldova 4.5 million and the Kyrgyz Republic 4.8 million. On the negative empirical relationship between trade policy and country size, see Wacziarg (1997).
} 
To the extent that public goods are of a non-rival nature, increasing returns stem from the fact that, while the required level of provision is independent of population size (or grows less than proportionately to it in the case of partial non-rivalry), the cost of public goods can be spread over a larger pool of taxpayers in larger countries. The following simple example illustrates this point: Consider a country composed of $\mathrm{N}$ identical individuals with constant elasticity of substitution utility functions. The social planner maximizes the utility of a representative individual:

$$
\mathrm{U}=\left(\mathrm{C}^{\alpha}+\mathrm{G}^{\alpha}\right)^{1 / \alpha} \quad(\alpha \leq 1)
$$

where $\mathrm{C}$ is private consumption and $\mathrm{G}$ is a non-rival public good. If the size of the population is $\mathrm{N}, \mathrm{Y}$ is the exogenously given level of individual income and taxes are lump-sum, then the individual budget constraint will be:

$C=Y-\frac{G}{N}$

The non-rival nature of the public good implies that every agent derives utility from consuming its aggregate supply G. However, each individual only pays a fraction $1 / \mathrm{N}$ of the total cost. The first order condition obtained from maximizing (1) subject to (2) leads to the following optimal supply of G:

$$
G=\frac{Y N}{(N)^{\frac{\alpha}{\alpha-1}}+1}
$$

This implies that the ratio of government spending to aggregate GDP, which is our variable of interest, is the following: 
$\frac{G}{\mathrm{YN}}=\frac{1}{\mathrm{~N}^{\frac{\alpha}{\alpha-1}}+1}$

and:

$\frac{\partial(G / Y N)}{\partial N}=-\left(\frac{\alpha}{\alpha-1}\right) \frac{N^{\frac{1}{\alpha-1}}}{\left(N^{\frac{\alpha}{\alpha-1}}+1\right)^{2}}$

This expression is negative whenever $\alpha<0$. The less substitutable $\mathrm{C}$ and $\mathrm{G}$ $(\alpha \rightarrow-\infty)$, the more we approach the case of a Leontief utility function, and the greater the effect of population on the government spending to GDP ratio. On the contrary, in the case of a unit elasticity of substitution $(\alpha=0)$, the utility function approaches a Cobb-Douglas and the effect of country size becomes zero. As the elasticity of substitution keeps increasing ( $\alpha=1$ corresponds to linear utility), the effect of population becomes positive.

The intuition here is that an increase in country size has two effects: it reduces the per capita cost of public goods for a given level of provision, allowing more private consumption, which corresponds roughly to a substitution effect, and it raises the optimal level of provision (this is akin to an income effect). The more substitutable private consumption and public goods, the more agents will be willing to increase their level of consumption of the public good as a result of a decrease in its per capita cost. In this case, the income effect dominates and country size will actually be positively related to the ratio of government spending to GDP. The empirical test for whether increasing 
returns to public goods provision lead to a smaller government to GDP ratio is essentially a test of whether the right-hand side of (5) is negative.

In summary, we will test for an inverse relationship between the size of a country and the share of government consumption and investment, that is, we will bring equation (5) to the data. Note that this argument is most relevant for government consumption of goods and services, while transfers should not be included in the definition of government spending for which increasing returns should apply.

\subsection{Some Basic Statistics}

Tables Ia describes all the variables used in this paper, while Table Ib presents basic correlations for these variables. We measure openness as the share of import and exports over GDP. Recently, Sachs and Warner (1995) and Wacziarg (1997) have constructed measures of trade policy openness for a large sample of countries. This is useful to evaluate the potential static and dynamic gains from switches in trade policy. However, the most relevant definition for our purposes is a measure of actual trade integration, which captures access to wider markets and also includes the gravity effect. Indeed, in the present paper we are interested in the fraction of the economy which actually "interacts" with the rest of the world. To measure government size we employ a variety of variables, in order to assess where increasing returns, if any, play the dominant role. 
The main variable under study is the share of government consumption in GDP, excluding interest payments, transfers and public investment.

The first five columns of Table II present univariate regressions of various measures of government size on the log of population. Government spending shares are measured for the five-year period 1980 to 1984 , which is the most recent period for which all the categories of outlays are available. Country size is negatively related to the share of government consumption, the share of total government current expenditures (including transfers and interest payments), the share of consumption spending excluding education, and the share of education related expenditures. Country size appears unrelated to defense spending and to public investment. ${ }^{3}$ The last column of Table II displays a very strong correlation between country size and trade openness. In this simple univariate regression, the log of population exhibits a highly significant negative coefficient, and alone explains $35 \%$ of the variation in trade openness.

For future reference, note that these results imply a positive correlation between openness and the size of government. Indeed, the simple correlation between various measures of government size and trade openness is generally positive, although it is essentially zero for the share of government consumption in GDP (Table Ib).

\footnotetext{
${ }^{3}$ For more discussions of defense spending in relation to economic variables, see Sandler and Hartley (1995). An important determinant of defense spending is, of course, the structure of international military alliances. So, while a small country in isolation may have to spend a lot per capita on defense to achieve a given level of military security, it may also opt to 'free ride' in an alliance with larger countries.
} 


\section{Further Empirical Results.}

To account for the possibility that the univariate regression results presented in Section 2 are driven by omitted variables, we now specify more complete equations for the determination of government size and openness. Tables III through V contain least squares estimates for the government size and openness equations, regressed on country size (measured by the log of population) and a set of other controls.

\subsection{Regressions for Government Size.}

We start by considering the determinants of the share of government consumption in GDP. Table IIIa presents estimates for the log of population when several controls are included sequentially, for the 1985-89 time period. The coefficient estimates are negative and significant in every specification, indicating the existence of increasing returns to the provision of public goods. It is noteworthy that the coefficient on size remains significant even after controlling for density and an exhaustive set of regional dummies. As expected, density enters negatively but does not eliminate the effect of size.

The interpretation of the coefficient on the $\log$ of population, in such a regression, is the following: If we refer to column (6) of Table IIIa, we can state that a $100 \%$ increase in population (doubling population) will lead to a $1.121^{*} \log 2$ points $(0.77$ 
points) decrease in public consumption as a percentage of GDP. In other words, just because Japan is twice the size of France means that it can "save" 0.77 points of GDP on its government consumption outlays. This represents savings of $4 \%$ on the sample mean cost of public consumption on goods and services.

Table IIIb examines the robustness of the country size coefficient with respect to different time periods. Our results suggest that the effect of country size has increased in time, both in terms of magnitude and in terms of statistical significance. While the point estimates are always negative, their absolute values and significance increased steadily since the 1960 's. One possible interpretation for this finding is that many newly decolonized countries, in the 1960 's, had yet to 'build up' their public sectors. As their governments converged to their equilibrium size, the effect of the fundamental determinants of government size started to play a larger and larger role. In particular, the negative effect of country size became more and more significant. Another hypothesis to explain this finding may simply be that government size may have been more poorly measured in the early periods, resulting in less precise estimates of the coefficients on the right hand side of the equation (note again that all point estimates remain negative throughout the periods; indeed, measurement error in the dependent variable should not induce bias, only loss of precision). In any case, the coefficient on size for the full period average (1960-84) is borderline significant at the $95 \%$ confidence level. 
While the government consumption share is the most widespread measure of government size, other categories of spending may relate differently to country size. Indeed, while we should expect expenditures related to non-excludable public goods such as roads, parks, and general administration to bear a negative relationship with country size, this cannot be expected to be the case for transfers, interest payments on the public debt and other forms of spending such as education and defense. These types of expenditures can be expected to be roughly proportional to a country's population, once their other determinants are held constant.

Table IV generally confirms these priors. Each of its columns corresponds to a different measure of government spending. Many of the control variables appear in every column, such as regional dummies, the log of per capita income as well as the measure of country size. The other controls differ slightly across equations, since the determinants of the various categories of government spending are likely to differ themselves. For instance, political instability, wars and ethnolinguistic fractionalization can be presumed to be strong determinants of defense spending. Similarly, urbanization rates can be presumed to determine government consumption and investment. ${ }^{4}$ For each spending category, controls were entered sequentially, and variables with insignificant coefficient estimates in everyone of the regressions were dropped (see Table IIIa for an example applied to the government consumption ratio).

\footnotetext{
${ }^{4}$ The exclusion of urbanization rates from the public investment equation resulted from its lack of statistical significance.
} 
Government consumption net of spending on defense and education bears a significantly negative coefficient, and this is not sensitive to the inclusion of any of the controls appearing in the column (2) of table IV. Similarly, this result is robust with respect to different time periods (contrary to the case of total government consumption examined above). ${ }^{5}$ However, when we move to the broadest available measure of government expenditure, which includes transfers and interest payments (column (3)), the effect of the log of population, while still negative, loses some of its statistical significance. The magnitudes of these effects, for columns (1) through (3), are roughly equal. This is in line with theoretical predictions. For instance, adding transfers and interest payments to government consumption should not modify the estimated effect of country size if the added categories are unrelated to it (with respect to the size coefficient, this is equivalent to adding noise to the dependent variable, which should only result - as it does - in reduced precision for the estimate).

Columns (4) and (5) contain estimates for government spending on defense and education (as a share of GDP) respectively. While defense spending seems unrelated to country size, the results for education related expenditures are somewhat more surprising. We indeed find evidence that larger countries tend to spend less on education, suggesting that some form of increasing returns may have found their way into this category of governmental activity. This may come as a surprise because education is not generally considered to be a non-excludable good, so that its cost should rise roughly

\footnotetext{
${ }^{5}$ Results for different specifications and different time periods are available upon request.
} 
proportionately to population (for a fixed desired level of educational services). However, the magnitude of the effect is much smaller than for columns (1) through (3). Again, these results are not sensitive to the inclusion of any single one of the controls that appear in columns (4) and (5) of table IV.

Lastly, column (6) examines the relationship between country size and the ratio of public investment to GDP. Although the coefficient on the $\log$ of population is negative, it is statistically insignificant and much smaller in magnitude than the corresponding estimate for "broad categories" of government outlays (columns (1)-(3)). This is also true when any of the control variables appearing in the public investment equation are excluded. However, one should note that the cross-country data for public investment are probably characterized by significant measurement error.

In summary, we do find evidence of increasing returns to the provision of publicly supplied goods, for a broad class of categories of public spending. The strongest effects, as expected, appear in the case of public consumption.

\subsection{Openness and Country Size}

In order to assess the relationship between country size and trade openness, we regressed the ratio of imports plus exports to GDP on several determinants of trade flows, including the log of population. We should stress that arguments linking country 
size and openness point to the possibility that these variables 'cause' each other (section 2). Hence, the coefficient on the $\log$ of population, in Table V, should not be interpreted as having any causal meaning. We just wish to illustrate the negative relationship between openness and country size, and the fact that this relationship is not driven by some omitted determinant of openness. This is indeed confirmed by the point estimates

presented in Table V. Country size is very significantly related to trade openness, even when a wide range of controls are included in the regression (on this point, see also Wacziarg, 1997). Furthermore, this result is not sensitive to the inclusion of any one of these controls, or to the time period under consideration. ${ }^{6}$ The magnitude of the coefficient on the log of population suggests that, once other determinants of openness are held constant, doubling population is associated with a $9 \%$ reduction in the trade to GDP ratio.

\section{Openness and Government Size}

If, as we argued above, smaller countries have larger governments and are also more open to trade, then it must follow that more open countries should have larger governments. However, this relationship would be spurious if country size is omitted from the government size equation.

\footnotetext{
${ }^{6}$ Results are available upon request.
} 
Rodrik (1996) instead argues for a channel linking openness to government size directly. If more open countries are more vulnerable to exogenous shocks such as shifts in their terms of trade originating from world markets, and if government spending is capable of stabilizing income and consumption, then more open countries will need a larger government to play a stabilizing role.

Column (1) of Table VI exactly reproduces Rodrik's base specification. He runs a cross-sectional regression for the $1980-84$ period, with the dependent variable being the $\log$ of the government consumption share in GDP. In addition to the log of openness, it includes eight control variables: the log of initial income, the log of the dependency ratio, the log of the urbanization rate and four regional dummies. Note that this specification omits country size. We readily replicate Rodrik's results in column (1), and confirm that openness enters with a significantly positive coefficient. ${ }^{7}$ When openness is excluded and the log of population is entered in its place, we obtain the result of section 2 , namely that the log of population enters with a negative sign. Column (3) adds the log of population in Rodrik's basic specification, and shows that, while openness remains significant, the measure of country size is not. However, the high degree of collinearity between openness and country size, documented above, makes it difficult to distinguish our channel (through country size) from Rodrik's direct effect. The next two columns in the table make this point clear.

\footnotetext{
${ }^{7}$ Rodrik's result does not depend on the choice of a particular time period, since the same result holds when the variables are averaged over 1960-89.
} 
Column (4) reports Rodrik's regression (on the year 1985) using not the log but the actual value of all the variables which are ratios, which is a more standard way to proceed (as, for instance, in the abundant cross-country growth literature). Indeed, the use of a $\log -\log$ specification imposes the restrictions that the elasticities of government size with respect to the openness ratio and to population are constant (and equal to the coefficients on the $\log$ of the openness and on the $\log$ of population, respectively). Instead of imposing such restrictions, we employ the actual government share, dependency ratio, and openness ratio. The result on openness now weakens substantially. Column (6) mirrors column (3), that is, it includes the log of population in the regression of column (4). The effect of openness disappears, while the log of population now seems to 'win the race' in terms of statistical significance. This provides evidence that the effect of openness on government size is in fact largely driven by the omission of country size in column (3).

Perhaps one way of reconciling the two channels is to argue that the country size effect should apply more specifically to government consumption, while the stabilizing role of government emphasized by Rodrik should apply more directly to governmental transfer payments. ${ }^{8}$ Table VII presents some fragments of evidence consistent with this view. In this table, we have added openness to the regressions presented in Table IV. The dependent variables are various components of government expenditures, all entering as a share of GDP. The dependent variable in column (1) is govern-

\footnotetext{
${ }^{8}$ Note however that Rodrik emphasizes government consumption in most of his analysis.
} 
ment consumption; population remains significant, while openness is totally insignificant, as in table VI. In column (2) the dependent variable is the government consumption share net of spending on defense and education. While the log of population here is still negative and highly significant, openness enters with the wrong sign (namely negative). This provides strong evidence in favor of our hypothesis, since this is precisely the category of government spending for which we would expect the greatest incidence of increasing returns. Column (3) considers total government current expenditures inclusive of transfers and interest payments. In this regression openness appears with a significantly positive coefficient, while the log of population bears an insignificant coefficient. The same pattern occurs for public investment (column (4)) and education (column (5)), while the share of expenditure on defense (column (6)) appears correlated neither with openness nor size.

\section{Conclusion}

The paper has documented the fact that country size is negatively related to government size, and that country size is negatively related to trade openness. These observations are consistent with recent economic theories of country forrnation. These models (Alesina and Spolaore, 1997) and Alesina, Spolaore and Wacziarg (1997) view the determination of country size as arising from a trade-off: large countries can afford to have smaller governments (and therefore lower taxes) and they already benefit from 
a sizable market which reduces their need to be open to trade. However, they must bear the cost of cultural heterogeneity.

Our results also suggest that the positive empirical association between trade openness and government size is due to a country size effect, especially for the government consumption part of government spending. The recent claim by Rodrik (1996) that more open countries are more subject to shocks and therefore need larger governments is more applicable to government transfers. The present paper has also provided some evidence consistent with this distinction between government consumption (determined by size rather than by openness) and government transfers (for which openness directly seems to play a greater role). 
Table Ia. Summary statistics and sources for the main variables

\begin{tabular}{|l|l|r|r|r|r|}
\hline \multicolumn{1}{|c|}{ Description } & \multicolumn{1}{|c|}{ Variable } & \multicolumn{1}{|c|}{ Source } & \# Obs & \multicolumn{1}{|c|}{ Mean } & Std.Dev \\
\hline Log population 1980 & LPOP80 & PWT 5.6 & 132 & 8.758 & 1.747 \\
\hline Log total GDP 1980 & LGDP80 & PWT 5.6 & 131 & 16.649 & 2.002 \\
\hline Log per capita income 1980 & LINI85 & PWT 5.6 & 137 & 7.871 & 1.061 \\
\hline Trade openness 1980-84 (\% GDP) & OPEN5 & PWT 5.6 & 133 & 73.851 & 47.582 \\
\hline Government consumption 1980-84 (\% GDP) & GOVSH5 & PWT 5.6 & 133 & 20.922 & 8.505 \\
\hline Govt current expenditure 1980-84 (\% GDP) & EXPEND5 & Barro-Lee & 103 & 23.998 & 11.581 \\
\hline Govt spending on education 1980-84 (\% GDP) & EDUC5 & Barro-Lee & 110 & 4.431 & 1.829 \\
\hline Govt spending on defense 1980-84 (\% GDP) & DEF5 & Barro-Lee & 118 & 4.345 & 4.751 \\
\hline Public investment 1980-84 (\% GDP) & PINVES5 & Barro-Lee & 114 & 8.757 & 4.845 \\
\hline Govt cons net of defense/educ 1980-84 (\% GDP) & ADMIN5 & Barro-Lee & 109 & 10.317 & 7.046 \\
\hline Urbanization rate 1990 (\%) & URB90 & World Bank & 135 & 48.984 & 24.832 \\
\hline Population density (pop/area) 1985 & DENSI85 & Barro-Lee & 138 & 160.040 & 521.110 \\
\hline Democracy index 1980-84 & DEMO5 & Gastil & 138 & 0.494 & 0.353 \\
\hline Ethnolinguistic fractionalization & FRACTION & Mauro & 112 & 41.821 & 29.683 \\
\hline Dependency ratio 1980 & POP6580 & Barro-Lee & 126 & 0.054 & 0.039 \\
\hline Number of revolutions per year 1980-85 & REVOLU5 & Banks & 137 & 0.178 & 0.272 \\
\hline War between 1960 and 1985 dummy & WARDUM & Barro-Lee & 137 & 1.189 & 1.737 \\
\hline Import duties / GDP) 1985-89 & IMPDUT6 & IMF-GFS & 108 & 0.121 & 0.108 \\
\hline Terms of trade shocks 1985-89 & NEWTOT6 & IMF & 136 & -0.016 & 0.053 \\
\hline Pre-Uruguay Round non-tariff barriers & NTPREUR & World Bank & 116 & 12.926 & 13.095 \\
\hline Log of land area & LAREA & Barro-Lee & 138 & 4.864 & 2.385 \\
\hline
\end{tabular}

PWT 5.6 refers to the Penn World Tables v. 5.6

Table Ib. Correlation matrix for selected variables (1980-84)

\begin{tabular}{|l|r|r|r|r|r|r|r|r|}
\hline & \multicolumn{1}{|c|}{ LPOP80 } & \multicolumn{1}{|c|}{ LGDP80 } & OPEN5 & GOVSH5 & EXPEND5 & EDUC5 & DEF5 & PINVES5 \\
\hline LGDP80 & 0.827 & 1 & & & & & & \\
\hline OPEN5 & -0.543 & -0.344 & 1 & & & & & \\
\hline GOVSH5 & -0.178 & -0.473 & -0.014 & 1 & & & & \\
\hline EXPEND5 & -0.168 & 0.131 & 0.327 & 0.174 & & & & \\
\hline EDUC5 & -0.200 & 0.037 & 0.324 & 0.244 & 0.662 & & & \\
\hline DEF5 & 0.161 & 0.122 & 0.012 & 0.367 & 0.390 & 0.281 & 1 & \\
\hline PINVES5 & -0.084 & -0.256 & 0.206 & 0.258 & -0.193 & 0.060 & 0.206 & 1 \\
\hline ADMIN5 & -0.257 & -0.577 & -0.124 & 0.710 & -0.225 & -0.171 & -0.317 & 0.104 \\
\hline
\end{tabular}

\# of obs: 86 
Table II. Univariate Regressions for Openness and Government Size (country size measured by the log of population)

\begin{tabular}{|l|r|r|r|r|r|r|r|}
\hline \multicolumn{1}{|c|}{$\begin{array}{c}\text { Dependent } \\
\text { Variable: }\end{array}$} & GOVSH5 & EXPEND5 & ADMIN5 & DEF5 & EDUC5 & PINVES5 & OPEN5 \\
\hline Constant & 28.946 & 33.696 & 17.548 & 2.833 & 6.684 & 10.572 & 214.748 \\
& $(7.12)$ & $(6.96)$ & $(5.07)$ & $(1.38)$ & $(6.68)$ & $(4.48)$ & $(12.72)$ \\
\hline Log population & -0.928 & -1.114 & -0.811 & 0.170 & -0.253 & -0.202 & -16.179 \\
$\mathbf{1 9 8 0}$ & $(-2.08)$ & $(-2.07)$ & $(-2.08)$ & $(0.79)$ & $(-2.33)$ & $(-0.80)$ & $(-9.58)$ \\
\hline R-Squared & .03 & .01 & .02 & .01 & .04 & .004 & .35 \\
\hline \# of Obs. & 131 & 101 & 109 & 118 & 109 & 114 & 131 \\
\hline
\end{tabular}

(t-statistics based on heteroskedastic-consistent (White-robust) standard errors, in parentheses)

Table IIIa. OLS regressions for the ratio of government consumption to GDP (1985-89)

\begin{tabular}{|c|c|c|c|c|c|c|}
\hline $\begin{array}{c}\text { Dependent variable: } \\
\text { Government consump- } \\
\text { tion / GDP (\%), 1985- } \\
89 \\
\end{array}$ & (1) & (2) & (3) & (4) & (5) & (6) \\
\hline Constant & $\begin{array}{r}27.656 \\
(7.69) \\
\end{array}$ & $\begin{array}{r}48.110 \\
(7.12) \\
\end{array}$ & $\begin{array}{r}48.477 \\
(7.07) \\
\end{array}$ & $\begin{array}{r}30.998 \\
(8.70) \\
\end{array}$ & $\begin{array}{r}56.868 \\
(5.18) \\
\end{array}$ & $\begin{array}{r}55.690 \\
(5.03) \\
\end{array}$ \\
\hline Log population 1985 & $\begin{array}{r}-0.795 \\
(-1.98)\end{array}$ & $\begin{array}{l}-0.856 \\
(-2.45)\end{array}$ & $\begin{array}{r}-0.880 \\
(-2.47) \\
\end{array}$ & $\begin{array}{r}-0.787 \\
(-2.32) \\
\end{array}$ & $\begin{array}{l}-1.133 \\
(-3.44) \\
\end{array}$ & $\begin{array}{l}-1.121 \\
(-3.39) \\
\end{array}$ \\
\hline $\begin{array}{l}\text { Log per capita income } \\
1985\end{array}$ & - & $\begin{array}{l}-1.840 \\
(-1.94) \\
\end{array}$ & $\begin{array}{l}-1.896 \\
(-1.98) \\
\end{array}$ & - & $\begin{array}{r}-2.258 \\
(-1.76) \\
\end{array}$ & $\begin{array}{l}-2.185 \\
(-1.70) \\
\end{array}$ \\
\hline Urbanization rate 1990 & - & $\begin{array}{l}-0.109 \\
(-2.34) \\
\end{array}$ & $\begin{array}{r}-0.097 \\
(-1.98) \\
\end{array}$ & - & $\begin{array}{r}-0.083 \\
(-1.95) \\
\end{array}$ & $\begin{array}{l}-0.068 \\
(-1.48) \\
\end{array}$ \\
\hline Population density 1985 & - & - & $\begin{array}{l}-0.002 \\
(-2.55) \\
\end{array}$ & - & - & $\begin{array}{r}-0.002 \\
(-1.67) \\
\end{array}$ \\
\hline Latin America dummy & - & - & - & $\begin{array}{r}-6.730 \\
(-2.80) \\
\end{array}$ & $\begin{array}{l}-6.780 \\
(-2.96) \\
\end{array}$ & $\begin{array}{l}-7.012 \\
(-3.06) \\
\end{array}$ \\
\hline $\begin{array}{l}\text { Sub-Saharan Africa } \\
\text { dummy }\end{array}$ & - & - & - & $\begin{array}{r}0.934 \\
(0.43) \\
\end{array}$ & $\begin{array}{r}-4.207 \\
(-1.54) \\
\end{array}$ & $\begin{array}{l}-3.975 \\
(-1.43) \\
\end{array}$ \\
\hline South East Asia dummy & - & - & - & $\begin{array}{l}-5.855 \\
(-2.07)\end{array}$ & $\begin{array}{l}-6.942 \\
(-3.02)\end{array}$ & $\begin{array}{l}-5.870 \\
(-2.41) \\
\end{array}$ \\
\hline OECD dummy & - & - & - & $\begin{array}{l}-9.629 \\
(-4.63)\end{array}$ & $\begin{array}{l}-5.142 \\
(-2.24)\end{array}$ & $\begin{array}{l}-5.672 \\
(-2.43)\end{array}$ \\
\hline SSR & 9917.36 & 7125.30 & 7029.41 & 7460.58 & 6401.80 & 6305.74 \\
\hline Adj. R-squared & 0.02 & 0.28 & 0.28 & 0.24 & 0.33 & 0.34 \\
\hline$\#$ of Obs. & 137 & 134 & 134 & 137 & 134 & 134 \\
\hline
\end{tabular}

(t-statistics based on heteroskedastic-consistent (White-robust) standard errors, in parentheses) 
Table IIIb. OLS regressions for the ratio of government consumption to GDP (different time periods)

\begin{tabular}{|c|c|c|c|c|c|c|}
\hline $\begin{array}{l}\text { Dependent variable: Government } \\
\text { consumption/GDP (\%) }\end{array}$ & $1960-64$ & $1965-69$ & $1970-74$ & $1975-79$ & $1980-84$ & $\begin{array}{c}1960-89 \\
\text { avg }\end{array}$ \\
\hline Constant & $\begin{array}{r}23.563 \\
(2.34) \\
\end{array}$ & $\begin{array}{r}16.641 \\
(1.53) \\
\end{array}$ & $\begin{array}{r}32.393 \\
(2.99) \\
\end{array}$ & $\begin{array}{r}50.232 \\
(3.84) \\
\end{array}$ & $\begin{array}{r}62.355 \\
(6.02) \\
\end{array}$ & $\begin{array}{r}39.191 \\
(3.71) \\
\end{array}$ \\
\hline Log population & $\begin{array}{r}-0.311 \\
(-0.86) \\
\end{array}$ & $\begin{array}{l}-0.158 \\
(-0.44) \\
\end{array}$ & $\begin{array}{l}-0.407 \\
(-1.02) \\
\end{array}$ & $\begin{array}{l}-0.875 \\
(-1.90) \\
\end{array}$ & $\begin{array}{l}-1.235 \\
(-3.46) \\
\end{array}$ & $\begin{array}{r}-0.721 \\
(-1.94) \\
\end{array}$ \\
\hline Log per capita income & $\begin{array}{c}-0.178 \\
(-0.12)\end{array}$ & $\begin{array}{r}0.946 \\
(0.58) \\
\end{array}$ & $\begin{array}{l}-1.029 \\
(-0.77)\end{array}$ & $\begin{array}{l}-2.364 \\
(-1.67)\end{array}$ & $\begin{array}{l}-3.269 \\
(-2.88)\end{array}$ & $\begin{array}{r}-1.129 \\
(-0.82)\end{array}$ \\
\hline Urbanization rate & $\begin{array}{r}-0.022 \\
(-0.43) \\
\end{array}$ & $\begin{array}{r}-0.042 \\
(-0.66) \\
\end{array}$ & $\begin{array}{r}0.012 \\
(0.21) \\
\end{array}$ & $\begin{array}{r}-0.010 \\
(-0.16) \\
\end{array}$ & $\begin{array}{r}-0.021 \\
(-0.45)\end{array}$ & $\begin{array}{r}-0.020 \\
(-0.35) \\
\end{array}$ \\
\hline Population density & $\begin{array}{r}-0.004 \\
(-2.82)\end{array}$ & $\begin{array}{r}-0.003 \\
(-1.81)\end{array}$ & $\begin{array}{l}-0.004 \\
(-2.18)\end{array}$ & $\begin{array}{r}-0.003 \\
(-1.67) \\
\end{array}$ & $\begin{array}{l}-0.003 \\
(-1.72)\end{array}$ & $\begin{array}{l}-0.003 \\
(-2.07)\end{array}$ \\
\hline Latin America dummy & $\begin{array}{l}-6.777 \\
(-4.19) \\
\end{array}$ & $\begin{array}{l}-7.191 \\
(-3.64) \\
\end{array}$ & $\begin{array}{l}-6.388 \\
(-2.75) \\
\end{array}$ & $\begin{array}{l}-6.601 \\
(-2.59) \\
\end{array}$ & $\begin{array}{l}-6.731 \\
(-3.05)\end{array}$ & $\begin{array}{l}-7.597 \\
(-3.64) \\
\end{array}$ \\
\hline Sub-Saharan Africa dummy & $\begin{array}{l}-3.428 \\
(-1.89) \\
\end{array}$ & $\begin{array}{l}-2.498 \\
(-1.22) \\
\end{array}$ & $\begin{array}{r}-0.463 \\
(-0.21)\end{array}$ & $\begin{array}{r}-1.716 \\
(-0.63) \\
\end{array}$ & $\begin{array}{l}-3.227 \\
(-1.21)\end{array}$ & $\begin{array}{r}-3.292 \\
(-1.43) \\
\end{array}$ \\
\hline South East Asia dummy & $\begin{array}{r}-3.015 \\
(-0.87) \\
\end{array}$ & $\begin{array}{r}-3.180 \\
(-0.75) \\
\end{array}$ & $\begin{array}{r}-2.742 \\
(-0.73) \\
\end{array}$ & $\begin{array}{r}-4.132 \\
(-1.33) \\
\end{array}$ & $\begin{array}{r}-4.053 \\
(-1.70) \\
\end{array}$ & $\begin{array}{l}-4.973 \\
(-1.58) \\
\end{array}$ \\
\hline OECD dummy & $\begin{array}{l}-6.026 \\
(-2.94) \\
\end{array}$ & $\begin{array}{r}-7.779 \\
(-3.30) \\
\end{array}$ & $\begin{array}{r}-6.933 \\
(-2.52)\end{array}$ & $\begin{array}{r}-5.220 \\
(-1.95) \\
\end{array}$ & $\begin{array}{r}-3.967 \\
(-1.75) \\
\end{array}$ & $\begin{array}{r}-7.267 \\
(-3.07) \\
\end{array}$ \\
\hline Adj. R-squared & .16 & .17 & .22 & .26 & .35 & .32 \\
\hline \# of Obs. & 118 & 119 & 124 & 125 & 130 & 118 \\
\hline
\end{tabular}

(t-statistics based on heteroskedastic-consistent (White-robust) standard errors, in parentheses) 
Table IV. OLS Regressions for various categories of public spending, (1980-84)

\begin{tabular}{|c|c|c|c|c|c|c|}
\hline & (1) & (2) & (3) & (4) & $(5)$ & (6) \\
\hline & $\begin{array}{c}\text { Public } \\
\text { Consump- } \\
\text { tion }\end{array}$ & $\begin{array}{l}\text { Pub. cons. } \\
\text { net of de- } \\
\text { fense and } \\
\text { education }\end{array}$ & \begin{tabular}{|c|} 
Expen- \\
diture incl. \\
transfers \\
and interest
\end{tabular} & $\begin{array}{c}\text { Public } \\
\text { spending } \\
\text { on defense }\end{array}$ & $\begin{array}{c}\text { Public } \\
\text { spending } \\
\text { on educa- } \\
\text { tion }\end{array}$ & $\begin{array}{l}\text { Public in- } \\
\text { vestment }\end{array}$ \\
\hline Constant & $\begin{array}{r}62.355 \\
(6.02) \\
\end{array}$ & $\begin{array}{r}48.395 \\
(3.60) \\
\end{array}$ & \begin{tabular}{r|}
19.350 \\
$(1.24)$ \\
\end{tabular} & $\begin{array}{r}-8.239 \\
(-1.29) \\
\end{array}$ & $\begin{array}{r}4.628 \\
(1.37) \\
\end{array}$ & $\begin{array}{r}9.658 \\
(1.62) \\
\end{array}$ \\
\hline Log population 1980 & \begin{tabular}{r|}
-1.235 \\
$(-3.46)$ \\
\end{tabular} & $\begin{array}{r}-1.030 \\
(-3.10) \\
\end{array}$ & $\begin{array}{l}-1.166 \\
(-1.59) \\
\end{array}$ & $\begin{array}{r}0.385 \\
(1.70) \\
\end{array}$ & $\begin{array}{r}-0.297 \\
(-2.28) \\
\end{array}$ & $\begin{array}{r}-0.369 \\
(-1.61) \\
\end{array}$ \\
\hline $\begin{array}{l}\text { Log per capita income } \\
1980\end{array}$ & $\begin{array}{l}-3.269 \\
(-2.88)\end{array}$ & $\begin{array}{l}-4.006 \\
(-2.62)\end{array}$ & $\begin{array}{r}2.246 \\
(1.41)\end{array}$ & $\begin{array}{r}1.968 \\
(2.30)\end{array}$ & $\begin{array}{r}0.252 \\
(0.74) \\
\end{array}$ & $\begin{array}{r}1.219 \\
(1.95) \\
\end{array}$ \\
\hline $\begin{array}{l}\text { Population density } \\
1980\end{array}$ & $\begin{array}{l}-0.003 \\
(-1.72) \\
\end{array}$ & - & $\begin{array}{l}-0.005 \\
(-1.63) \\
\end{array}$ & - & $\begin{array}{r}-0.001 \\
(-1.74)\end{array}$ & $\begin{array}{r}-0.001 \\
(-2.74) \\
\end{array}$ \\
\hline $\begin{array}{l}\text { Democracy index 1980- } \\
84\end{array}$ & - & $\begin{array}{r}3.823 \\
(1.41) \\
\end{array}$ & - & $\begin{array}{r}-4.830 \\
(-2.30)\end{array}$ & $\begin{array}{r}0.857 \\
(1.16)\end{array}$ & $\begin{array}{l}-3.395 \\
(-1.92) \\
\end{array}$ \\
\hline Dependency ratio 1980 & - & - & $\begin{array}{r}125.384 \\
(2.29)\end{array}$ & - & 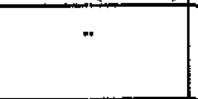 & $\begin{array}{r}-46.715 \\
(-2.86)\end{array}$ \\
\hline Urbanization rate & $\begin{array}{l}-0.021 \\
(-0.45)\end{array}$ & $\begin{array}{l}-0.028 \\
(-0.74) \\
\end{array}$ & - & - &. & - \\
\hline $\begin{array}{l}\text { Ethnolinguistic frac- } \\
\text { tionalization }\end{array}$ & - & $\begin{array}{r}0.048 \\
(1.99)\end{array}$ & $\begin{array}{l}-0.080 \\
(-1.81)\end{array}$ & $\begin{array}{l}-0.028 \\
(-1.99)\end{array}$ & " & - \\
\hline War dummy (1960-85) & - & - & - & $\begin{array}{r}0.454 \\
(1.36)\end{array}$ &. & - \\
\hline Revolutions $1980-84$ & - & - & - & $\begin{array}{r}3.016 \\
(2.27) \\
\end{array}$ & - & - \\
\hline Latin America dummy & $\begin{array}{l}-6.731 \\
(-3.05)\end{array}$ & $\begin{array}{r}-0.004 \\
(0.00)\end{array}$ & $\begin{array}{r}-12.511 \\
(-2.97) \\
\end{array}$ & $\begin{array}{l}-4.931 \\
(-2.31) \\
\end{array}$ & $\begin{array}{l}-0.562 \\
(-0.99) \\
\end{array}$ & $\begin{array}{r}-4.238 \\
(-3.01) \\
\end{array}$ \\
\hline $\begin{array}{l}\text { Sub-Saharan Africa } \\
\text { dummy }\end{array}$ & $\begin{array}{l}-3.227 \\
(-1.21)\end{array}$ & $\begin{array}{r}0.017 \\
(0.00) \\
\end{array}$ & $\begin{array}{l}-3.635 \\
(-0.99)\end{array}$ & $\begin{array}{l}-3.172 \\
(-2.02) \\
\end{array}$ & $\begin{array}{r}0.192 \\
(0.28) \\
\end{array}$ & $\begin{array}{l}-2.881 \\
(-2.06) \\
\end{array}$ \\
\hline $\begin{array}{l}\text { South East Asia } \\
\text { dummy }\end{array}$ & $\begin{array}{r}-4.053 \\
(-1.70)\end{array}$ & $\begin{array}{r}-2.803 \\
(-0.99) \\
\end{array}$ & $\begin{array}{l}-5.831 \\
(-1.38)\end{array}$ & $\begin{array}{l}-5.446 \\
(-3.45) \\
\end{array}$ & $\begin{array}{r}0.108 \\
(0.17) \\
\end{array}$ & $\begin{array}{l}-1.227 \\
(-0.81) \\
\end{array}$ \\
\hline OECD dummy & $\begin{array}{r}-3.967 \\
(-1.75)\end{array}$ & $\begin{array}{r}0.986 \\
(0.51) \\
\end{array}$ & $\begin{array}{r}-8.883 \\
(-1.02) \\
\end{array}$ & $\begin{array}{r}-6.193 \\
(-2.34) \\
\end{array}$ & $\begin{array}{c}0.558 \\
(0.73) \\
\end{array}$ & $\begin{array}{l}-3.357 \\
(-1.55) \\
\end{array}$ \\
\hline Adj. R-squared & .35 & .41 & .43 & .35 & .15 & .32 \\
\hline \# of Obs. & 130 & 101 & 911 & 108 & 109 & 111 \\
\hline
\end{tabular}

(t-statistics based on heteroskedastic-consistent (White-robust) standard errors, in parentheses)

Note: All dependent variables enter as percentage points of GDP. All regressions are for the 1980-84 period. 
Table V. OLS estimates of the openness equation (imports plus exports / GDP, \%)

\begin{tabular}{|c|c|c|c|c|c|c|}
\hline $\begin{array}{l}\text { Dependent Variable: } \\
\text { Trade to GDP Ratio (\%) }\end{array}$ & $\begin{array}{c}(1) \\
1970-74 \\
\end{array}$ & \begin{tabular}{|c|}
$(2)$ \\
$1975-79$ \\
\end{tabular} & $\begin{array}{c}3) \\
1980-84 \\
\end{array}$ & $\begin{array}{c}(4) \\
1985-89 \\
\end{array}$ & $\begin{array}{c}(5) \\
1985-89 \\
\end{array}$ & $\begin{array}{c}(6) \\
1985-89\end{array}$ \\
\hline Constant & $\begin{array}{r}181.175 \\
(5.11)\end{array}$ & $\begin{array}{r}209.179 \\
(4.76) \\
\end{array}$ & $\begin{array}{r}190.737 \\
(4.01) \\
\end{array}$ & $\begin{array}{r}207.091 \\
(11.55)\end{array}$ & $\begin{array}{r}183.126 \\
(8.27)\end{array}$ & $\begin{array}{r}152.864 \\
(2.60)\end{array}$ \\
\hline Log Population & $\begin{array}{r}-13.913 \\
(-5.07) \\
\end{array}$ & $\begin{array}{r}-15.196 \\
(-5.66) \\
\end{array}$ & $\begin{array}{r}-16.634 \\
(-5.58) \\
\end{array}$ & $\begin{array}{r}-15.065 \\
(-8.86) \\
\end{array}$ & $\begin{array}{l}-7.590 \\
(-1.86) \\
\end{array}$ & $\begin{array}{r}-13.059 \\
(-3.48) \\
\end{array}$ \\
\hline Log Area & $\begin{array}{l}-3.881 \\
(-1.58) \\
\end{array}$ & $\begin{array}{l}-4.809 \\
(-1.59) \\
\end{array}$ & $\begin{array}{l}-4.900 \\
(-1.31)\end{array}$ & - & $\begin{array}{l}-7.687 \\
(-1.93)\end{array}$ & $\begin{array}{l}-5.596 \\
(-1.48) \\
\end{array}$ \\
\hline Terms of trade shocks & $\begin{array}{r}79.328 \\
(1.69) \\
\end{array}$ & $\begin{array}{r}-149.302 \\
(-2.81) \\
\end{array}$ & $\begin{array}{r}11.466 \\
(0.07) \\
\end{array}$ & - & $\begin{array}{r}92.240 \\
(1.49) \\
\end{array}$ & $\begin{array}{r}73.703 \\
(1.37) \\
\end{array}$ \\
\hline Import Duty Ratio & $\begin{array}{r}-69.836 \\
(-2.39)\end{array}$ & \begin{tabular}{|r|}
-62.849 \\
$(-2.13)$ \\
\end{tabular} & $\begin{array}{r}-25.475 \\
(-0.79)\end{array}$ & - & $\begin{array}{r}-59.280 \\
(-1.67)\end{array}$ & $\begin{array}{r}-12.765 \\
(-0.36)\end{array}$ \\
\hline $\begin{array}{l}\text { Pre-Uruguay Round non-tariff barri- } \\
\text { ers }\end{array}$ & $\begin{array}{l}-0.064 \\
(-0.30)\end{array}$ & $\begin{array}{l}-0.264 \\
(-1.08)\end{array}$ & $\begin{array}{l}-0.073 \\
(-0.28)\end{array}$ & - &. & $\begin{array}{l}-0.045 \\
(-0.17)\end{array}$ \\
\hline Log initial income & $\begin{array}{r}4.292 \\
(1.28) \\
\end{array}$ & $\begin{array}{r}5.276 \\
(0.96) \\
\end{array}$ & $\begin{array}{r}8.287 \\
(1.62) \\
\end{array}$ & - & - & $\begin{array}{r}8.151 \\
(1.40)\end{array}$ \\
\hline Oil exporter dummy & $\begin{array}{r}-8.507 \\
(-0.50) \\
\end{array}$ & $\begin{array}{r}17.600 \\
(2.41) \\
\end{array}$ & $\begin{array}{r}1.820 \\
(0.23) \\
\end{array}$ & $\begin{array}{r}-6.040 \\
(-0.98) \\
\end{array}$ & $\begin{array}{r}12.848 \\
(1.34) \\
\end{array}$ & $\begin{array}{r}9.524 \\
(0.92) \\
\end{array}$ \\
\hline Sub-Saharan Africa dummy & $\begin{array}{r}1.912 \\
(0.28) \\
\end{array}$ & $\begin{array}{r}-9.719 \\
(-1.25)\end{array}$ & $\begin{array}{l}-6.067 \\
(-0.69)\end{array}$ & $\begin{array}{r}-14.498 \\
(-2.23) \\
\end{array}$ & $\begin{array}{r}-1.218 \\
(-0.15) \\
\end{array}$ & $\begin{array}{r}5.187 \\
(0.61) \\
\end{array}$ \\
\hline South-East Asia dummy & $\begin{array}{r}38.643 \\
(1.63) \\
\end{array}$ & $\begin{array}{r}47.503 \\
(1.28) \\
\end{array}$ & $\begin{array}{r}64.230 \\
(1.44) \\
\end{array}$ & $\begin{array}{r}34.060 \\
(1.60) \\
\end{array}$ & $\begin{array}{r}29.365 \\
(1.20) \\
\end{array}$ & $\begin{array}{r}66.508 \\
(1.75) \\
\end{array}$ \\
\hline OECD dummy & $\begin{array}{l}-2.047 \\
(-0.27) \\
\end{array}$ & $\begin{array}{r}-22.192 \\
(-1.87) \\
\end{array}$ & $\begin{array}{r}-12.660 \\
(-1.24) \\
\end{array}$ & $\begin{array}{r}2.780 \\
(0.35) \\
\end{array}$ & $\begin{array}{r}-4.945 \\
(-0.60) \\
\end{array}$ & $\begin{array}{r}-8.043 \\
(-0.69) \\
\end{array}$ \\
\hline Latin America dummy & $\begin{array}{r}-11.631 \\
(-1.91) \\
\end{array}$ & $\begin{array}{r}-28.470 \\
(-3.69) \\
\end{array}$ & $\begin{array}{r}-27.298 \\
(-3.66) \\
\end{array}$ & $\begin{array}{r}-17.588 \\
(-2.56) \\
\end{array}$ & $\begin{array}{r}-10.450 \\
(-1.42)\end{array}$ & $\begin{array}{r}-17.139 \\
(-2.32)\end{array}$ \\
\hline Adj. R-squared & .66 & .63 & .57 & .44 & .50 & .55 \\
\hline$\#$ of Obs. & 85 & 95 & 97 & 137 & 107 & 90 \\
\hline
\end{tabular}

(t-statistics based on heteroskedastic-consistent (White-robust) standard errors, in parentheses) 
Table VI. Regression results: Replication of Rodrik's base regression. (sensitivity to log-log specification)

\begin{tabular}{|c|c|c|c|c|c|c|}
\hline \multirow{2}{*}{$\begin{array}{c}\text { Dependent variable: Ratio } \\
\text { of government consump- } \\
\text { tion to GDP }(\%) \\
1985-89 \\
\end{array}$} & \multicolumn{3}{|c|}{ All ratios enter in logs } & \multicolumn{3}{|c|}{ No ratios enter in logs } \\
\hline & (1) & (2) & (3) & (4) & (5) & (6) \\
\hline Constant & $\begin{array}{r}3.452 \\
(6.41) \\
\end{array}$ & $\begin{array}{r}4.871 \\
(8.27) \\
\end{array}$ & $\begin{array}{r}3.718 \\
(5.36) \\
\end{array}$ & $\begin{array}{r}41.168 \\
(4.64) \\
\end{array}$ & $\begin{array}{r}56.888 \\
(5.44) \\
\end{array}$ & $\begin{array}{r}53.288 \\
(4.95) \\
\end{array}$ \\
\hline Log population 1985 & - & $\begin{array}{l}-0.056 \\
(-3.35) \\
\end{array}$ & $\begin{array}{r}-0.017 \\
(-0.66) \\
\end{array}$ & - & $\begin{array}{l}-0.996 \\
(-3.16) \\
\end{array}$ & $\begin{array}{l}-0.897 \\
(-2.10) \\
\end{array}$ \\
\hline Openness ratio $1975-84$ & $\begin{array}{r}0.190 \\
(4.12) \\
\end{array}$ & - & $\begin{array}{r}0.152 \\
(2.14) \\
\end{array}$ & $\begin{array}{r}0.031 \\
(1.97) \\
\end{array}$ & - & $\begin{array}{r}0.008 \\
(0.43) \\
\end{array}$ \\
\hline Log initial income 1985 & $\begin{array}{l}-0.141 \\
(-3.13) \\
\end{array}$ & $\begin{array}{l}-0.159 \\
(-2.96) \\
\end{array}$ & $\begin{array}{r}-0.142 \\
(-3.08) \\
\end{array}$ & $\begin{array}{r}-2.146 \\
(-1.84) \\
\end{array}$ & $\begin{array}{l}-2.859 \\
(-2.43) \\
\end{array}$ & $\begin{array}{r}-2.467 \\
(-2.11) \\
\end{array}$ \\
\hline Dependency ratio 1985 & $\begin{array}{r}-0.139 \\
(-1.35)\end{array}$ & $\begin{array}{r}-0.094 \\
(-0.95)\end{array}$ & $\begin{array}{l}-0.146 \\
(-1.38)\end{array}$ & $\begin{array}{r}-25.675 \\
(-0.75) \\
\end{array}$ & $\begin{array}{r}-21.259 \\
(-0.65)\end{array}$ & $\begin{array}{r}-32.220 \\
(-0.93) \\
\end{array}$ \\
\hline Urbanization ratio 1990 & $\begin{array}{r}-0.142 \\
(-2.21) \\
\end{array}$ & $\begin{array}{r}-0.101 \\
(-1.52) \\
\end{array}$ & $\begin{array}{r}-0.132 \\
(-2.03)\end{array}$ & $\begin{array}{c}-0.063 \\
(-1.54) \\
\end{array}$ & $\begin{array}{r}-0.040 \\
(-1.05) \\
\end{array}$ & $\begin{array}{l}-0.043 \\
(-1.06) \\
\end{array}$ \\
\hline OECD dummy & $\begin{array}{l}-0.082 \\
(-0.50)\end{array}$ & $\begin{array}{l}-0.119 \\
(-0.70)\end{array}$ & $\begin{array}{l}-0.081 \\
(-0.48)\end{array}$ & $\begin{array}{r}-2.592 \\
(-0.69)\end{array}$ & $\begin{array}{l}-2.608 \\
(-0.74)\end{array}$ & $\begin{array}{l}-2.449 \\
(-0.65) \\
\end{array}$ \\
\hline Latin America dummy & $\begin{array}{r}-0.235 \\
(-2.26) \\
\end{array}$ & $\begin{array}{r}-0.305 \\
(-2.98) \\
\end{array}$ & $\begin{array}{r}-0.258 \\
(-2.44) \\
\end{array}$ & $\begin{array}{l}-4.638 \\
(-1.93) \\
\end{array}$ & $\begin{array}{r}-5.891 \\
(-2.75) \\
\end{array}$ & $\begin{array}{l}-5.991 \\
(-2.43) \\
\end{array}$ \\
\hline South East Asia dummy & $\begin{array}{r}-0.544 \\
(-3.96) \\
\end{array}$ & $\begin{array}{r}-0.436 \\
(-3.39) \\
\end{array}$ & $\begin{array}{r}-0.528 \\
(-3.81) \\
\end{array}$ & $\begin{array}{l}-8.874 \\
(-3.75) \\
\end{array}$ & $\begin{array}{l}-7.272 \\
(-3.47) \\
\end{array}$ & $\begin{array}{l}-8.037 \\
(-3.72) \\
\end{array}$ \\
\hline Sub-Saharan Africa dummy & $\begin{array}{l}-0.239 \\
(-2.51)\end{array}$ & $\begin{array}{r}-0.258 \\
(-2.47) \\
\end{array}$ & $\begin{array}{r}-0.255 \\
(-2.51)\end{array}$ & $\begin{array}{l}-4.129 \\
(-1.68) \\
\end{array}$ & $\begin{array}{l}-5.350 \\
(-2.06)\end{array}$ & $\begin{array}{l}-5.319 \\
(-2.03)\end{array}$ \\
\hline Socialist dummy & $\begin{array}{r}0.263 \\
(2.26) \\
\end{array}$ & $\begin{array}{r}0.289 \\
(2.37) \\
\end{array}$ & $\begin{array}{r}0.273 \\
(2.29) \\
\end{array}$ & $\begin{array}{r}5.984 \\
(2.04) \\
\end{array}$ & $\begin{array}{r}6.586 \\
(2.21) \\
\end{array}$ & $\begin{array}{r}6.545 \\
(2.20) \\
\end{array}$ \\
\hline Adjusted R-squared & .50 & .48 & .50 & .39 & .41 & .40 \\
\hline \# of obs. & 122 & 124 & 122 & 122 & 124 & 122 \\
\hline
\end{tabular}

(t-statistics based on heteroskedastic-consistent (White-robust) standard errors, in parentheses)

Column I corresponds to Rodrik's base regression. Numbers differ slightly because we use dependency ratios from Barro Lee rather than from the World Bank. 
Table VII. OLS Regressions for various categories of public spending, 1980-84, includes trade openness

\begin{tabular}{|c|c|c|c|c|c|c|}
\hline & $\begin{array}{l}\text { Public } \\
\text { Consump- } \\
\text { tion }\end{array}$ & $\begin{array}{l}\text { Pub. cons. } \\
\text { net of de- } \\
\text { fense and } \\
\text { education }\end{array}$ & $\begin{array}{c}\text { Expen- } \\
\text { diture incl. } \\
\text { transfers } \\
\text { and interest }\end{array}$ & $\begin{array}{c}\text { Public } \\
\text { spending } \\
\text { on defense }\end{array}$ & $\begin{array}{c}\text { Public } \\
\text { spending } \\
\text { on educa- } \\
\text { tion } \\
\end{array}$ & $\begin{array}{l}\text { Public in- } \\
\text { vestment }\end{array}$ \\
\hline & (1) & (2) & (3) & (4) & (5) & (6) \\
\hline Constant & $\begin{array}{r}61.387 \\
(5.72) \\
\end{array}$ & $\begin{array}{r}53.956 \\
(3.71) \\
\end{array}$ & $\begin{array}{l}-5.105 \\
(-0.35) \\
\end{array}$ & $\begin{array}{r}-10.155 \\
(-1.60) \\
\end{array}$ & $\begin{array}{r}1.858 \\
(0.53) \\
\end{array}$ & $\begin{array}{r}4.393 \\
(0.76) \\
\end{array}$ \\
\hline Log population 1980 & $\begin{array}{l}-1.134 \\
(-2.45)\end{array}$ & $\begin{array}{l}-1.465 \\
(-3.48) \\
\end{array}$ & $\begin{array}{r}1.356 \\
(1.69) \\
\end{array}$ & $\begin{array}{r}0.608 \\
(2.02) \\
\end{array}$ & $\begin{array}{r}-0.011 \\
(-0.05)\end{array}$ & $\begin{array}{r}0.228 \\
(0.89) \\
\end{array}$ \\
\hline Openness 1980-84 & $\begin{array}{r}0.006 \\
(0.32) \\
\end{array}$ & $\begin{array}{r}-0.021 \\
(-1.82) \\
\end{array}$ & $\begin{array}{l}0.163 \\
(4.61) \\
\end{array}$ & $\begin{array}{r}0.012 \\
(0.93) \\
\end{array}$ & $\begin{array}{r}0.015 \\
(1.39) \\
\end{array}$ & $\begin{array}{r}0.034 \\
(2.26) \\
\end{array}$ \\
\hline $\begin{array}{l}\text { Log per capita income } \\
1980\end{array}$ & $\begin{array}{r}-3.311 \\
(-2.89) \\
\end{array}$ & $\begin{array}{l}-4.113 \\
(-2.67) \\
\end{array}$ & $\begin{array}{r}1.183 \\
(0.68) \\
\end{array}$ & $\begin{array}{r}1.842 \\
(2.09) \\
\end{array}$ & $\begin{array}{r}0.134 \\
(0.41) \\
\end{array}$ & $\begin{array}{r}0.868 \\
(1.34)\end{array}$ \\
\hline \begin{tabular}{|l} 
Population density \\
1980 \\
\end{tabular} & $\begin{array}{r}-0.003 \\
(-1.24) \\
\end{array}$ & - & $\begin{array}{l}-0.021 \\
(-4.59) \\
\end{array}$ & - & $\begin{array}{l}-0.001 \\
(-0.96)\end{array}$ & $\begin{array}{l}-0.002 \\
(-1.30) \\
\end{array}$ \\
\hline Dependency ratio 1980 & - & - & $\begin{array}{r}128.217 \\
(2.39) \\
\end{array}$ & - & - & $\begin{array}{r}-46.825 \\
(-2.77) \\
\end{array}$ \\
\hline $\begin{array}{l}\text { Democracy index } 1980- \\
84\end{array}$ & - & $\begin{array}{l}4.016 \\
(1.45) \\
\end{array}$ & - & $\begin{array}{l}-4.796 \\
(-2.29)\end{array}$ & $\begin{array}{r}0.918 \\
(1.25) \\
\end{array}$ & $\begin{array}{l}-3.126 \\
(-1.86) \\
\end{array}$ \\
\hline Urbanization rate 1990 & $\begin{array}{r}-0.023 \\
(-0.48) \\
\end{array}$ & $\begin{array}{r}-0.013 \\
(-0.34) \\
\end{array}$ & - & \begin{tabular}{|l|}
- \\
\end{tabular} & - & - \\
\hline $\begin{array}{l}\text { Ethnolinguistic frac- } \\
\text { tionalization }\end{array}$ & - & $\begin{array}{r}0.047 \\
(1.95) \\
\end{array}$ & $\begin{array}{l}-0.092 \\
(-2.96) \\
\end{array}$ & $\begin{array}{l}-0.028 \\
(-2.06) \\
\end{array}$ & - & - \\
\hline War dummy (1960-85) & - & - & - & $\begin{array}{r}0.441 \\
(1.32) \\
\end{array}$ & - & - \\
\hline Revolutions 1980-84 & - & - & - & $\begin{array}{r}3.202 \\
(2.45) \\
\end{array}$ & - & - \\
\hline Latin America dummy & $\begin{array}{l}-6.554 \\
(-2.79)\end{array}$ & $\begin{array}{r}-0.816 \\
(-0.34) \\
\end{array}$ & $\begin{array}{l}-8.031 \\
(-1.67) \\
\end{array}$ & $\begin{array}{l}-4.601 \\
(-2.04) \\
\end{array}$ & $\begin{array}{r}-0.156 \\
(-0.25) \\
\end{array}$ & $\begin{array}{l}-3.230 \\
(-2.25) \\
\end{array}$ \\
\hline $\begin{array}{l}\text { Sub-Saharan Africa } \\
\text { dummy }\end{array}$ & $\begin{array}{l}-3.212 \\
(-1.20) \\
\end{array}$ & $\begin{array}{r}-0.175 \\
(-0.04) \\
\end{array}$ & $\begin{array}{l}-2.463 \\
(-0.72)\end{array}$ & $\begin{array}{r}-3.122 \\
(-2.00) \\
\end{array}$ & $\begin{array}{r}0.312 \\
(0.48) \\
\end{array}$ & $\begin{array}{r}-2.605 \\
(-1.91) \\
\end{array}$ \\
\hline $\begin{array}{l}\text { South East Asia } \\
\text { dummy }\end{array}$ & $\begin{array}{l}-4.174 \\
(-1.76) \\
\end{array}$ & $\begin{array}{l}-1.609 \\
(-0.60) \\
\end{array}$ & $\begin{array}{l}-9.400 \\
(-2.40) \\
\end{array}$ & $\begin{array}{l}-6.078 \\
(-3.72) \\
\end{array}$ & $\begin{array}{r}-0.343 \\
(-0.51) \\
\end{array}$ & $\begin{array}{l}-2.017 \\
(-1.39) \\
\end{array}$ \\
\hline OECD dummy & $\begin{array}{r}-3.868 \\
(-1.67) \\
\end{array}$ & $\begin{array}{r}0.608 \\
(0.30) \\
\end{array}$ & $\begin{array}{r}-7.691 \\
(-0.86) \\
\end{array}$ & $\begin{array}{l}-6.028 \\
(-2.22) \\
\end{array}$ & $\begin{array}{r}0.673 \\
(0.90) \\
\end{array}$ & $\begin{array}{r}-2.906 \\
(-1.38) \\
\end{array}$ \\
\hline Adj. R-squared & .34 & .42 & .53 & .35 & .21 & .36 \\
\hline$\#$ of Obs. & 130 & 101 & 91 & 108 & 109 & 111 \\
\hline
\end{tabular}

(t-statistics based on heteroskedastic-consistent (White-robust) standard errors, in parentheses)

Note: All dependent variables enter as percentage points of GDP. All regressions are for the $1980-84$ period. 


\section{References}

Ades, Alberto F. and Edward L. Glaeser, 1994, Evidence on Growth, Increasing Returns and the Extent of the Market, NBER Working Papers no. 4714, April.

Alesina, Alberto, and Enrico Spolaore (1997), On the Number and Size of Nations, forthcoming, Quarterly Journal of Economics.

Alesina, Alberto, Enrico Spolaore and Romain Wacziarg, (1997), Economic Integration and Political Disintegration, mimeo, Harvard University, February.

Alesina, Alberto, Reza Baqir and William Easterly (1996), Public Goods and Ethnic Divisions, mimeo, October.

Cameron, David R., (1978), The Expansion of the Public Economy, American Political Science Review, 72, 1243-1261.

Murphy, Kevin M., Andrei Shleifer and Robert W. Vishny, 1989, Industrialization and the Big Push, Journal of Political Economy, vol. 97, no. 5, pp. 1003-1026.

Rodrik, Dani, (1996), Why do More Open Countries Have Bigger Governments, NBER Working Paper \# 5537, April.

Sachs, Jeffrey and Andrew Warner (1995), Economic Reform and the Process of Global Integration, Brookings Papers on Economic Activity, no.1, p. 1-118.

Sandler T. and K. Hartley (1995), The Economics of Defense, Cambridge: Cambridge University Press.

Wacziarg, Romain, (1997), Measuring the Dynamic Gains from Trade, mimeo, Harvard University and World Bank, February. 